\title{
On the Effects of COVID-19 outbreak on the Nigerian Stock Exchange performance: Evidence from GARCH Models
}

\section{Monday Osagie ${ }^{1,2}$ Adenomon; Bilkisu Maijamaa ${ }^{1}$ \& Daniel Owoicholofu ${ }^{1}$ John}

\author{
1. Department of Statistics \& NSUK-LISA Stat Lab \\ Nasarawa State University, Keffi (NSUK), Nasarawa State, Nigeria. \\ 2. Foundation of Laboratory for Econometrics and Applied Statistics of Nigeria (FOUND- \\ LEAS-IN-NIGERIA) \\ adenomonmo@nsuk.edu.ng ; bilkisuahmad971@gmail.com; danielojohn@ yahoo.com; \\ $+2347036990145$
}

\begin{abstract}
COVID-19 was first identified in Wuhan, China in December 2019 and has caused huge death and has spread to almost all the parts of the world. There are speculation that most of the world economy and financial markets would be affected due to lockdown and social distancing. The first case of COVID-19 was first identified in Nigeria on 27th February 2020 and this study examines the effect of COVID-19 outbreak on the performance of the Nigeria stock exchange using historical data covering $2^{\text {nd }}$ March 2015 to $16^{\text {th }}$ April, 2020 sourced from a secondary source. This study considered the COVID-19 period from 2nd January 2020 to $16^{\text {th }}$ April 2020, the results revealed a loss in stock returns and high volatility in stock returns under the COVID-19 period in Nigeria as against the normal period under study. In addition, Quadratic GARCH (QGARCH) and Exponential GARCH (EGARCH) models with dummy variable were applied to the stock returns shows that the COVID-19 has had negative effect on the stock returns in Nigeria. The study recommended that political and economic policy such as stable political environment, incentive to indigenous companies, diversification of the economy, flexible exchange rate regime be implemented so as to improve the financial market and to attract more and new investors to the Nigerian Stock Exchange.
\end{abstract}

Keywords: Nigerian Stock Exchange (NSE), COVID-19, QGARCH, EGARCH, Returns.

\section{Introduction}

COVID-19 is regarded as a public health emergency of international concern. Patients contracting the severe form of the disease constitute approximately $15 \%$ of the cases 
(WHO, 2020). Older people and those with pre-existing medical conditions are likely to develop serious illness (Li et al. 2020). The Coronavirus disease 2019 (COVID-19) which first occurred in Wuhai, China in December 2019 has spread to almost all the of the world (Akanni and Gabriel, 2020). As reported in Gralinski and Menachey (2020) the seafood market in Wuhan was closed down because of the incidence of this COVID-19 disease. Also Causing huge number of deaths (Al-qaness et al. 2020; https://www.worldometers.info/coronavirus/), falling global oil price and economic lockdown of major economy of the world such as USA (Ajami, 2020) of which Nigeria is not left out of the negative impact of the COVID-19 (Akanni and Gabriel, 2020). Igwe (2020) argued that the world economy faces worst-ever economic recession due to the outbreak of the COVID-19. Igwe noted that this shock from this virus can increase volatility that can impact negatively on the economic and financial system of any country. Adesina (2020) stated global equitable market has lost about 24 billion USD of which about 22 billion lost in United states GDP. In a recent study by Feinstein (2020) on Zombie outbreak which can be similar to COVID-a9, the study concluded a moderate zombie outbreak leaving 1 million people dead in major industrialized nation can lead to drop in GDP and Financial market by $23.44 \%$ and $29.30 \%$ respectively.

In Nigeria, COVID-19 case was officially identified on 27th February 2020 and few more cases was identified after then (Effiong, et al. 2020). The consequences of COVID-19 on the economy and financial markets in Nigeria are: economic lockdown of major cities (Abuja, Lagos, Ogun states) on 30th March 2020 leading to economic loss especially for 
daily income earners from small-medium scale businesses, withdrawal of money by investors from the market and fall in oil prices (Ozili, 2020) and on the global economiy, the impact of the COVID-19 cannot also be overemphasized (Mckibbin and Fernando, 2020) because it can lead to huge external debt of any country.

To assess the possible impact of corona virus on the Nigerian financial market and economy, it is of great importance not to focus only on the epidemiological profile of the virus but also its impact on the economy. This enlightened sense of uncertainties will affect the economy in various ways such as businesses, household and financial market participation. Businesses may hold off on investments because of uncertainties of supply chain as well as international and national customers. Household worried about contacting the virus, could cut off spending on items that are luxuries. As well as health risk possesses real economic risk especially with lack of health insurance by many households in Nigeria which will lead to large bills when the get sick. This will lead to less spending and hence less economy growth.

From the foregoing, if the impacts of COVID-19 on the economy and financial markets are not properly understood and managed, this virus has the potential to totally crash health sector or economy of any country such as Nigeria (Anjorin 2020; Feinstein 2020) especially in the absence of vaccine (Okhuese, 2020a) although study have shown that a recovered population may not be reinfected (Okhuese, 2020b). 


\section{Literature Review}

The coronavirus pandemic is corona virus disease which has affected many, leading to deaths and have had great impact on Nigeria stock market, these have attracted a lot of scholars to investigate the pandemic. Ozili and Arun (2020) studied the impact of covid-19 on the global economy reveal that covid-19 have huge negative impact on Nigeria stock market in which the virus encouraged social distancing which led to a close of financial markets, corporate offices, businesses and events. The speed in which the virus spread exponentially can result to damage of safety in consumption and investment among investors, consumers and trade partners. Similarly, Chukwuka and Ekeruche (2020) researched on understanding the impact of the COVID-19 outbreak on the Nigerian economy, the study shows Nigeria economy was estimated GDP in 2020 of $2.5 \%$ increase, this have been truncated by the pandemic and lead to high increase of the nation's debt services and revenue ratio at $60 \%$ amid the falling prices of oil has been a great source of concern to policy makers as this will make it stiff for the economy to grow. This study is consistent with Oladeinde (2020) which examined Coronavirus and Nigeria Cuts Oil Benchmark to \$30, Slashes Capital Budget By 20\% which was discovered that Nigeria will make significant change in its 2020 budget to contain the effect of the outbreak of corona virus pandemic on the nation's economy. The bench mark for crude was placed at $\$ 57$ per barrel is set to drop down to $\$ 30$ per barrel, this shows that Nigeria will experience much reduction in the revenue and projects than what was planned. The report of International Monetary Fund (IMF) also show global 
growth will fall by $0.5 \%$ in 2020 due to the covid-19 pandemic, the effects shows that there will be Stiffness of Demand and supply, sharp decrease in commodity and tourism arrivals. it was predicted that by the first half of the year, the global economy might enter into recessionn, as the result of huge inability to process raw material and respond to high demand of goods and services. Also, Akanni and Gabriel (2020) investigated The Implication of COVID-19 on the Nigerian Economy, it was discovered covid-19 pandemic lead to disruption of activities and economy instability like the united trade and development agency has cost the outbreak of the pandemic to be at about $\$ 2$ trillion. It was seen that factors like social distancing, stay at home, limitation in spending and supply factor which include; cutting or stopping production and output have negative impact on economy growth. These have led to increasing poverty and unemployment rate, the National Bureau of Statistics (NBS) report 2020 placed Nigeria 21 among 181 counties with high unemployment rate of $23.1 \%$, it is estimated that about 87million surviving with less than $\$ 2$ a day benchmark.

Olufemi and Bolanle (2018) examined the International portfolio diversification in the Nigerian stock market, the study was concluded using vector autoregressive granger causality test for relationship shows there is no relationship between Nigeria stock market and the five other developed countries. But applying the Generalized Method of Moments regression, the result shows during crisis and pre crisis period that developed stock markets have impact on the Nigeria stock market during crisis period. This was further concluded that Nigeria stock market is safe for investors before the covid-19 
crisis but this looming pandemic that shock the world economy has made it difficult to invest. Also, Alex et al (2020) used Microscopic Markov chain approach to investigate a mathematical model for the spatiotemporal epidemic spreading of COVID19. It was concluded that at the first half of April 2020, the pandemic will be at its peak, and incubation period of 5.2days in which the condition is still asymptomatic, the beat fit is 2.86days as asymptomatic infection period which later is 3.2 days except its mild symptoms in young people, The fatality rate was fixes at $42 \%$ of ICU patient, which from ICU to death is estimated to 7 days and those recovering from ICU spend 10days. Ndedi (2020) studied the aftermath of the Coronavirus in Selected African Economies. The study concludes that countries like Nigeria and Angola are going to feel the pain as they majorly depend on crude oil to have a stable economy and manufacturers of good and services, importation of foods have been tightened. It will further lead to African strong economic countries like Nigeria, South Africa, Angola, Egypt and Algeria will experience fiscal pressure due to sharp drop of commodity price. Lastly, John (2020) examined COVID-19 Pandemic, a War to be won and understanding its Economic Implications for Africa. The study concludes that the International Monetary Fund has called on creditors of all official bilateral to suspend all debt payment as forbearance is requested by International Development Association Countries to savage the economy instability, and further added that there will be substantial cost on the economy as the pandemic continue to spread which require strong will and action by the people and government to continue a war against it. The full impact of covid-19 on the African 
economy cannot be determined now, but there will be more insight into it as situation unfolds.

Therefore the goal of this paper examined the impact of the COVID-19 pandemic on the Nigerian Stock markets using Quadratic GARCH (QGARCH) and Exponential GARCH models.

The remaining parts paper is structured as follows: Section 3 describes the source of the datasets and presents the results of the descriptive statistics and unit root and Arch tests. Section 4 presents the framework for QGARCH and EGARCH approaches used. Section 5 presents the results, while Section 5 provides conclusion and some policy implications.

\section{Data and Descriptive Statistics}

The data used in this study was collected from www.investing.com. Daily All Share Price (ASP) of the Nigerian Stock Exchange (NSE) from 2nd March 2015 to $16^{\text {th }}$ April 2020 (a total of 1270) was collected from the website. The period was used to avoid the effect of the 2008 to 2009 global financial crisis. The returns was calculated using the formula below

$$
R_{t}=\ln P_{t}-\ln P_{t-1}
$$

where $R_{t}$ is return at time $\mathrm{t}$; ln is the natural logarithm; $P_{t}$ is the current daily stock price at time $\mathrm{t}$, and $P_{t-1}$ is the previous daily stock price at time $t-1$. After the time lag is accounted for, then a total observation becomes 1269. 
The All Share Price (ASP) of NSE got to its peak between 2017 and 2018 but begins to drop during late 2019 and 2020 which are the COVID-19 period as shown in Fig. 1 while the log of All Share Price (ASP) of the NSE is presented in Fig. 2 that also unveil the information as shown in Fig. 1.

In Fig. 3 presents the log returns of the ASP of the NSE for the period of $3^{\text {rd }}$ March 2015 to $16^{\text {th }}$ April 2020. Evidences of volatility are shown between 2015 and 2016, 2017 and 2018, and late 2019 and in 2020.

\section{INSERT FIGURE 1 ABOUT HERE}

\section{INSERT FIGURE 2 ABOUT HERE}

\section{INSERT FIGURE 3 ABOUT HERE}

In Fig. 4 we presented the log returns of the NSE refer to as Non Covid 19 period from 03/03/2015 to 31/12/2019 while in Fig. 5 we presented the log returns of the NSE refer to as Covid 19 period from 02/01/2020 to 16/04/2019.

\section{INSERT FIGURE 5 ABOUT HERE}

\section{INSERT FIGURE 6 ABOUT HERE}

Table 1 presented descriptive statistics for the price and log returns for the full sample. The mean returns is negative which signifies a loss in stock, the returns is skewed and leptokurtic (highly peaked and fat tailed). Likewise the returns rate presented for the non covid 19 and covid 19 periods. But for the covid 19 period, the 
returns exhibited high volatility as compared to the non covid 19 period as shown in Table 2. Lastly, the returns for the full sample, non covid 19 and covid 19 periods revealed presence of arch effects.

\section{INSERT TABLE 1 ABOUT HERE}

\section{INSERT TABLE 2 ABOUT HERE}

Table 3 and 4 presented unit root test using Augmented Dickey-Fuller (ADF), Dickey-Fuller Generalized least square (DF-GLS) and Phillips-Perron (PP) statistic for the price and log returns for the full sample, log returns for non covid 19 and covid 19 periods. The results shows that the price is not stationary while the log returns is stationary for full and sub samples.

\section{INSERT TABLE 3 ABOUT HERE}

\section{INSERT TABLE 4 ABOUT HERE}

\section{Methodology}

\subsection{EGARCH Model}

The exponential GARCH (EGARCH) model was first proposed by Nelson (1991) to overcome some weaknesses of the GARCH model in handling financial time series. With particular interest to allow for asymmetric effects between positive and negative asset returns, Nelson (1991) considered the weighted innovation as follows:

$$
g\left(\varepsilon_{t}\right)=\theta \varepsilon_{t}+\gamma\left[\left|\varepsilon_{t}\right|-\mathrm{E}\left(\left|\varepsilon_{t}\right|\right)\right]
$$


where $\theta$ and $\gamma$ are real constants. Both $\varepsilon_{t}$ and $\left|\varepsilon_{t}\right|-\mathrm{E}\left(\left|\varepsilon_{t}\right|\right)$ are zero-mean iid sequences with continuous distributions. Therefore, $E\left[g\left(\varepsilon_{t}\right)\right]=0$. The asymmetry of $g\left(\varepsilon_{t}\right)$ can easily be seen by rewriting it as

$$
g\left(\varepsilon_{t}\right)=\left\{\begin{array}{l}
(\theta+\gamma) \varepsilon_{t}-\gamma E\left(\left|\varepsilon_{t}\right|\right) \text { if } \varepsilon_{t} \geq 0 \\
(\theta-\gamma) \varepsilon_{t}-\gamma E\left(\left|\varepsilon_{t}\right|\right) \text { if } \varepsilon_{t}<0
\end{array}\right.
$$

An $\operatorname{EGARCH}(\mathrm{m}, \mathrm{s})$ model can be written as be written as follows (Emenogu et al. 2020):

$$
\begin{aligned}
& a_{t}=\sigma_{t} \varepsilon_{t} \\
& \ln \left(\sigma_{t}^{2}\right)=\omega+\sum_{i=1}^{s} \alpha_{i} \frac{\left|a_{t-i}\right|+\theta_{i} a_{t-i}}{\sigma_{t-i}}+\sum_{j=1}^{m} \beta_{j} \ln \left(\sigma_{t-i}^{2}\right)
\end{aligned}
$$

which specifically results in $\operatorname{EGARCH}(1,1)$ being written as

$$
\begin{aligned}
& a_{t}=\sigma_{t} \varepsilon_{t} \\
& \ln \left(\sigma_{t}^{2}\right)=\omega+\alpha\left(\left[\left|a_{t-1}\right|-\mathrm{E}\left(\left|a_{t-1}\right|\right)\right]\right)+\theta a_{t-1}+\beta \ln \left(\sigma_{t-1}^{2}\right)
\end{aligned}
$$

where $\left|a_{t-1}\right|-\mathrm{E}\left(\left|a_{t-1}\right|\right)$ are iid and mean zero. When the EGARCH model has a Gaussian distribution of error term, $\mathrm{E}\left(\left|\varepsilon_{t}\right|\right)=\sqrt{2 / \pi}$, which gives:

$$
\ln \left(\sigma_{t}^{2}\right)=\omega+\alpha\left(\left[\left|a_{t-1}\right|-\sqrt{2 / \pi}\right]\right)+\theta a_{t-1}+\beta \ln \left(\sigma_{t-1}^{2}\right)
$$

\subsection{Quadratic GARCH (QGARCH)}

Sentana (1995) first introduced Quadratic GARCH (QGARCH) model to cope with asymmetric effects of shocks on volatility. In addition, Quadratic-GARCH is an important time series model used mostly in econometrics and finance such as returns on stocks, foreign exchange rate with volatility variance with time. It is used to model 
asymmetric effects of positive and negative shocks, it is a very important time, adequately representation of volatility and risk and can easily be incorporated in multivariate models (Andersen and Bollerslev, (1998); Bou-Hamad and Jamali (2020); Hølleland and Karlsen (2020); Holý and Tomanová (2020)).

The QGARCH $(1,1)$ can be specified as follows:

$r_{t=} \mu+\varepsilon_{t}, \varepsilon_{t}=\sigma_{t} z_{t}, z_{t} \sim N(0,1)$

$\sigma_{t}^{2}=\omega+\alpha \varepsilon_{t-1}^{2}+\beta \sigma_{t-1}^{2}+\gamma \varepsilon_{t-1}$

the term $\gamma \varepsilon_{t-1}$ often makes it possible for positive and negative shocks to have different effects on conditional volatility (Yaya and Shittu, 2010).

\section{Results}

In Table 5, we presented the performances of the EGARCH and QGARCH models with Generalized Error Distribution (GED), Student $t$ distribution (STD) and Skewed Student $\mathrm{t}$ distribution (SSTD) using Akaike Information Criteria (AIC) to choice the best model among the competing GARCH models. The result revealed EGARCH $(1,1)$ with SSTD model emerged the best model. Hence EGARCH(1,1) with SSTD was used to model the full sample incorporating dummy (non covid 19 period is 0 and covid 19 period as 1$)$.

INSERT TABLE 5 ABOUT HERE 
In Table 6, we presented the result of the EGARCH $(1,1)$ with SSTD by incorporating the Covid 19 period. The result revealed a negative impact of covid 19 on the stock returns in Nigeria under the period under study. This result is consistent with the results of Ozili and Arun (2020) and Akanni and Gabriel (2020).

\section{INSERT TABLE 6 ABOUT HERE}

\section{Conclusion and Policy implications}

In this study we investigate the effect of Covid-19 on the performance of Nigerian Stock Exchange (NSE) market because of speculation of the devastating effect of this virus on world economy and financial market. We consider the historical data of the daily All Share Price (ASP) of the Nigerian Stock Exchange (NSE) from 2nd March 2015 to $16^{\text {th }}$ April 2020.

The descriptive statistics for the price and log returns for the full sample. The mean returns is negative which signifies a loss in stock, the returns is skewed and leptokurtic (highly peaked and fat tailed). Likewise the returns rate presented for the non covid 19 and covid 19 periods. But for the covid 19 period, the returns exhibited high volatility as compared to the non covid 19 period. Lastly, the returns for the full sample, non covid 19 and covid 19 periods revealed presence of arch effects.

This study employed EGARCH and QGARCH models with addition of dummy variable to allow for non covid 19 and covid 19 period. We found that EGARCH $(1,1)$ with SSTD by incorporating the Covid 19 period emerged the best model among the 
competing models. The result revealed a negative impact of covid 19 on the stock returns in Nigeria under the period under study.

The study recommended that political and economic policy such as stable political environment, incentive to indigenous companies, diversification of the economy, flexible exchange rate regime be implemented so as to improve the financial market and to attract more and new investors to the Nigerian Stock Exchange. 


\section{References}

Africa union report (2020) Impact of the corona virus (covid-19) on the Africa economy

Ajami, R. (2020). Globalization, the challenge of COVID-19 and Oil Price Unvcertainty. Journal of Asia-Pacific Business, doi:10.1080/10599231.2020.1745046.

Akanni, L. O. and Gabriel, S. C. (2020). The implication of COVID-19 on the Nigerian Economy. http://cseaafrica.org/the-implication-of-covid19-on-th-nigerian-economy/ retrieved on 08-04-2020.

Albulescu, C. (2020). Coronavirus and Oil Price Cash. http://dx.doi.org/10.2139/ssrn.3553452.

Alex A, Wesley C, Jesus GG, Sergio G, Clara G, Joan TM, David S, Benjamin S (2020). A mathematical model for the spatiotemporal epidemic spreading of COVID19. medRxiv preprint doi: https:// doi.org/10.1101/2020.03.21.20040022.

Al-qaness, M. A. A., Ewees, A. A., Fan, H. and Aziz, M. A. E. (2020). Optimization Method for forecasting confirmed cases of COVID-19 in China. J. Clin. Med, 9,674. Doi:10.3390/jcm9030674

Andersen, T. G., \& Bollerslev, T. (1998). Deutsche mark-dollar volatility: intraday activity patterns, macroeconomic announcements, and longer run dependencies. the Journal of Finance, 53(1), 219-265.

Anjorin, A. A. (2020). More Preparedness on Coronavirus Disease-2019 (COVID-19) in Nigeria. Pan Afri. J. Life Sci. 4:200-203 
Bou-Hamad, I., \& Jamali, I. (2020). Forecasting financial time-series using data mining models: A simulation study. Research in International Business and Finance, 51, 101072. https//doi.org/10.1016/j.ribaf.2019.101072

Chen, M.-Y.(2013). Time Series Analysis: Conditional Volatility Models. National Chung Hsing University, Taiwan.

Chukwuka O, Mma AE ( 2020) Understanding the impact of the COVID-19 outbreak on the Nigerian Economy. 8 April 2020. www.brookings.edu.

Effiong, A. I., Ime, R. N., Akpan, E. J., Mfreke, U. J., Edidiong, I. F., Abere, O. J., Abraham, U. P., Essien, M. O. and Ukpong, E. S. (2020): Assessment of Nigerian Television Authority (NTA) Ongoing Programme Awaresness Campaigns on Corona Virus in Nigeria. Electronic Res. J. Soc. Sci. \& Hum. 2(1):130-141.

Emenogu, G. N.; Adenomon, M. O and Nweze, N. O.(2020); On the Volatility of Daily Stock Returns of Total Petroleum Company of Nigeria: Evidence from GARCH Models, Value-at-Risk and Backtesting, Financial Innovation, 6:18, https://doi.org/10.1186/s40854-020-00178-1

Feinstein, Z. (2020). Reanimating a Dead Economy: Financial and Economic Analysis of the Zombie Outbreak. Arxiv:2003.09943vi[q-fin-GN) 22 March 2020.

Gralinski, L. E. and Menachery, V. D. (2020). Return of the Coronavirus: 2019-nCov. Viruses, 12,135. Doi:10.3390/v12020135.

Hølleland, S., \& Karlsen, H. A. (2020). A Stationary Spatio-Temporal GARCH Model. Journal of Time Series Analysis, 41(2), 177-209. 
Holý, V., \& Tomanová, P. (2020). Streaming Perspective in Quadratic Covariation Estimation Using Financial Ultra-High-Frequency Data. arXiv preprint arXiv:2003.13062.

Igwe, P. A. (2020). Coronavirus with Looming Global Health and Economic Doom. African Development Institute of research methodology, 1(1):1-6

John E A (2020). COVID-19 Pandemic, a War to be Won: Understanding its Economic Implications for Africa. Appl Health Econ Health Policy. 2020 Apr 5 : 1-4. doi: 10.1007/s40258-020-00580-x [Epub ahead of print] PMCID: PMC7130452.

Li, Q.; Guan, X., Wu, P., Wang, X. et al. (2020). Early Transmission Dynamics in Wuhan, China, of Novel Coronavirus-Infected Pneumonia. New England Journal of Medicine 382:1199-1207.

McKibbin, W. and Fernando, R. (2020). The Global Macroeconomic Impacts of COVID19. Seven Scenarios CAMA working paper 19/2020 https:// ssrn.com/abstract $=3547729$

Ndedi A A (2020) The Aftermath of the Coronavirus in Selected African Economies (April 1, 2020). Available at SSRN: https://ssrn.com/abstract $=3565931$.

Nelson D (1991) Conditional heteroskedasticity in asset pricing: A new approach. Econometrica 59, 347-370.

Okhuese, V. A. (2020a). Mathematical Predictions for COVID-19 as a Global Pandemic. MedRxiv preprint doi:https:// doi.org/10.1101/2020.03.19.20038794

Okhuese, V. A. (2020b). Estimation of the Probability of reinfection with COVID-19 Coronavirus by the SEIRUS Model. MedRxiv preprint doi:https:// doi.org/10.1101/2020.04.02. 20050930 
Oladeinde O (2020) Nigeria: Coronavirus - Nigeria Cuts Oil Benchmark to \$30, Slashes Capital Budget By 20\% Premium Times Abuja.

Olufemi AA, Bolanle A (2018) International portfolio diversification in the Nigerian stock market: A global financial crisis perspective. Future Business Journal. 4(2):189-194. https://doi.org/10.1016/j.fbj.2018.06.001.

Ozili P, Arun T (2020) Spillover of COVID 19, impact on the global Economy.10.2139 \ssrn.3562570.

Ozili, P. (2020). COVID-19 Pandemic and Economic Crisis: The Nigerian Experience and Structural Causes. https:// ssrn.com/abstract $=3571085$

Sentana, E. (1995). Quadratic ARCH Models. Review of Economic Studies 62:639-661

WHO (2020). Novel Coronavirus (2019-nCoV) Situation Report-7 - World Health Organization (WHO), January 27, 2020.

Yaya, O. S. and Shittu, O. I. (2010): On the Impact of Inflation and Exchange Rate on Conditional Stock Market Volatility: A Re-Assessment. American Journal of Scientific and Industrial Research, 1(2):115-117.

World Health Organization (WHO, 2020): Situation Report March 2020; Corona virus (COVID-19). 


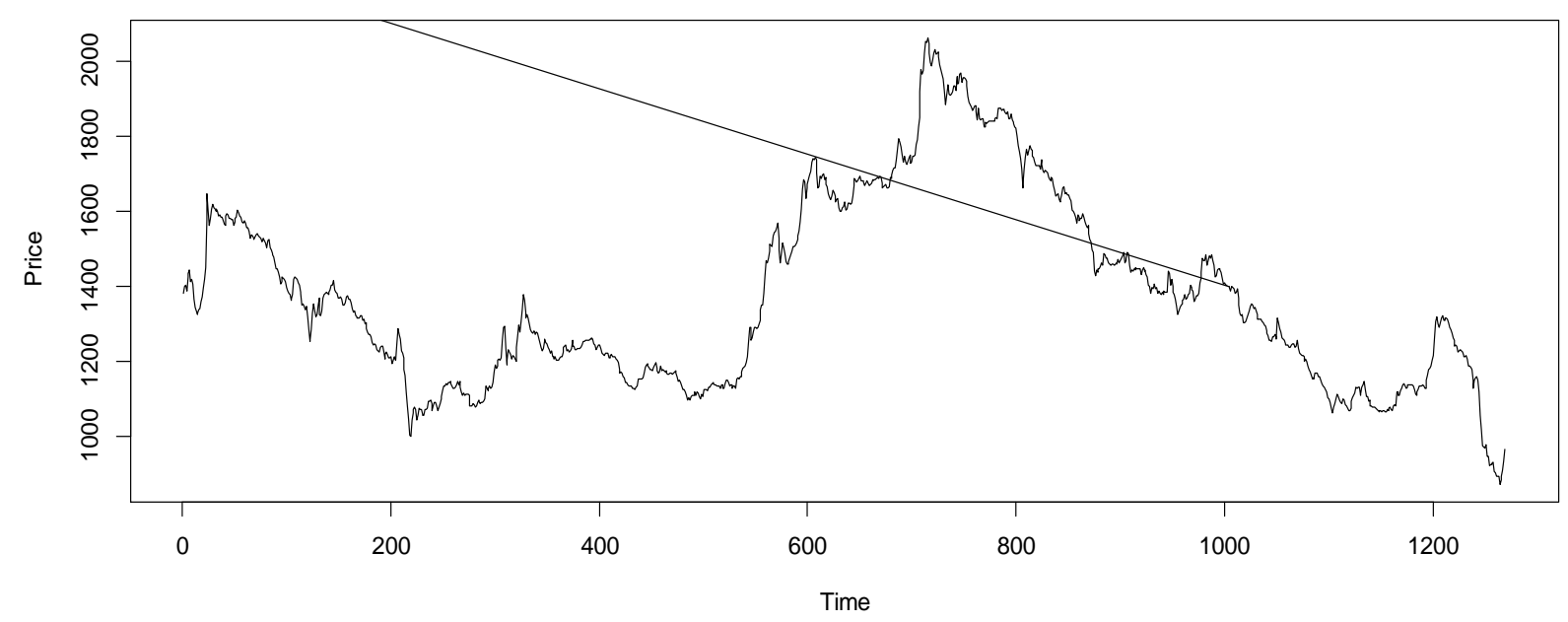

Fig. 1: Time Plot of NSE Stock Price

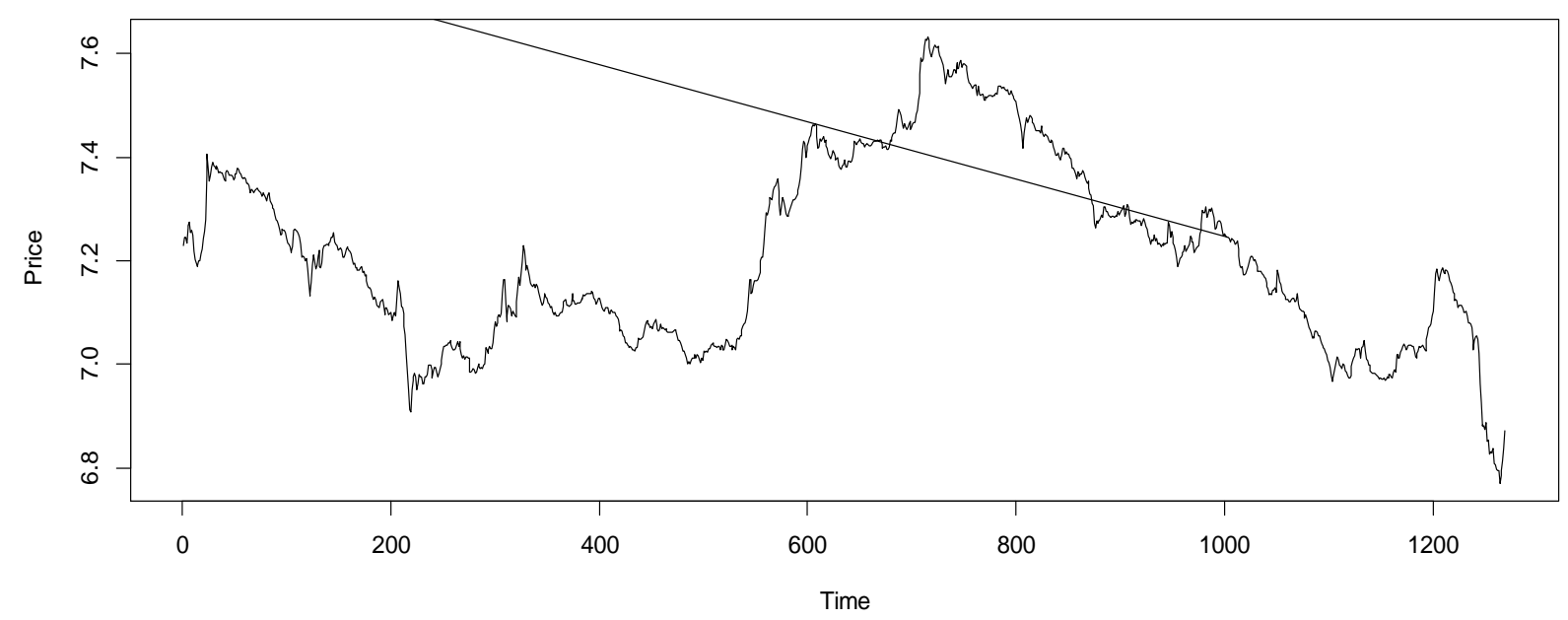

Fig 2: Time Plot of NSE log Stock Price 


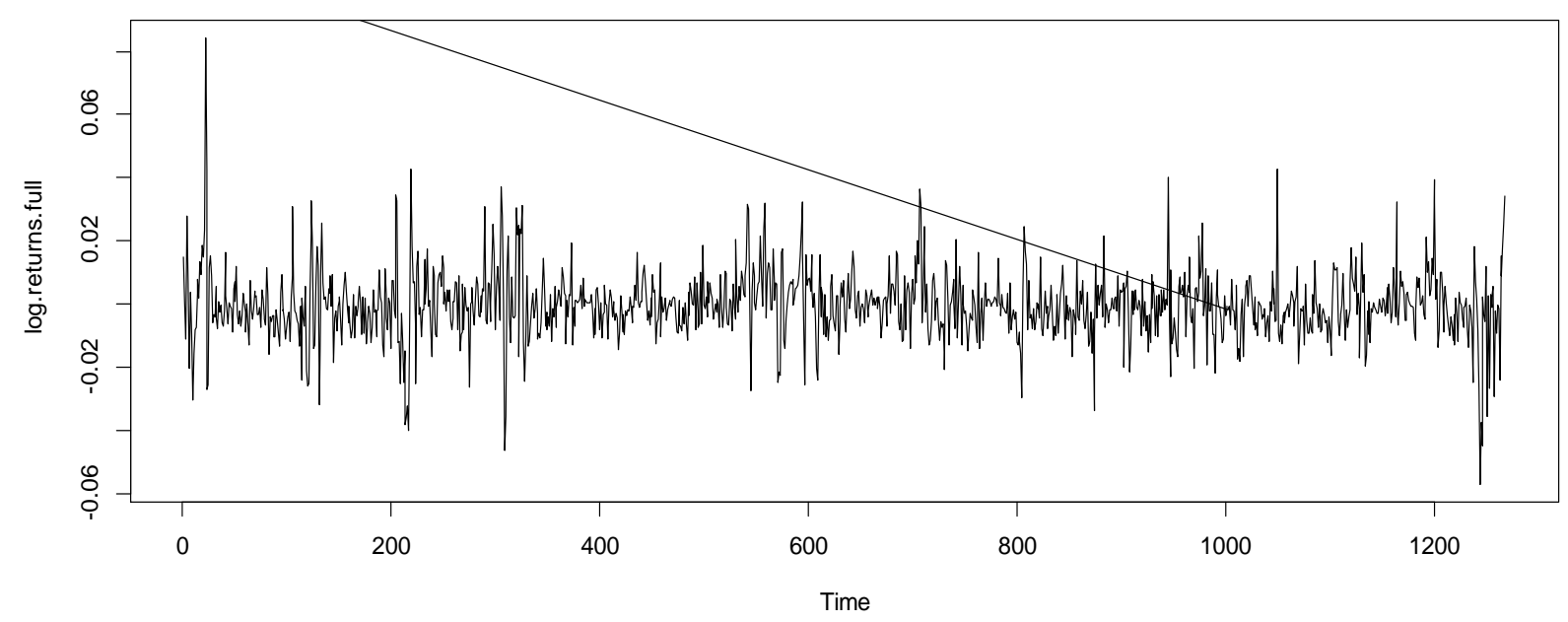

Fig. 3: Time Plot of NSE log Returns

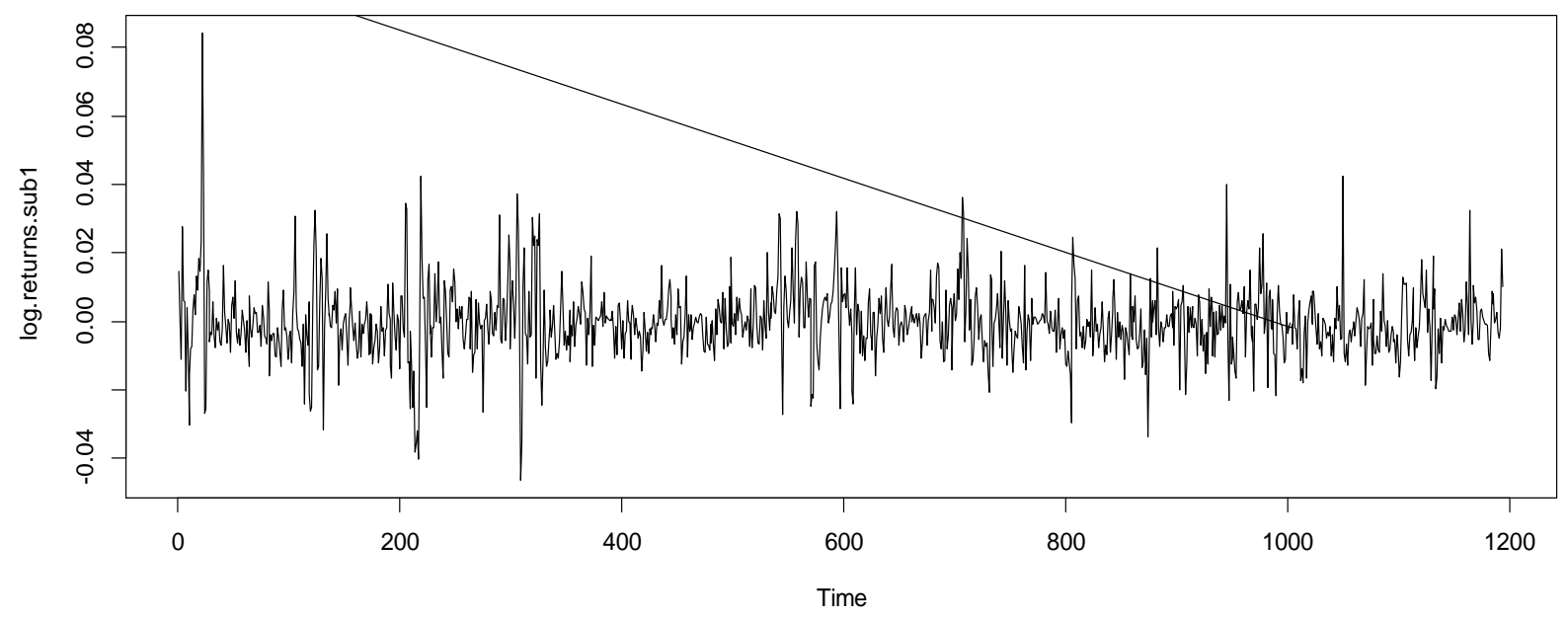

Fig 4: Time Plot for NSE log Returns for Non Covid 19 period 


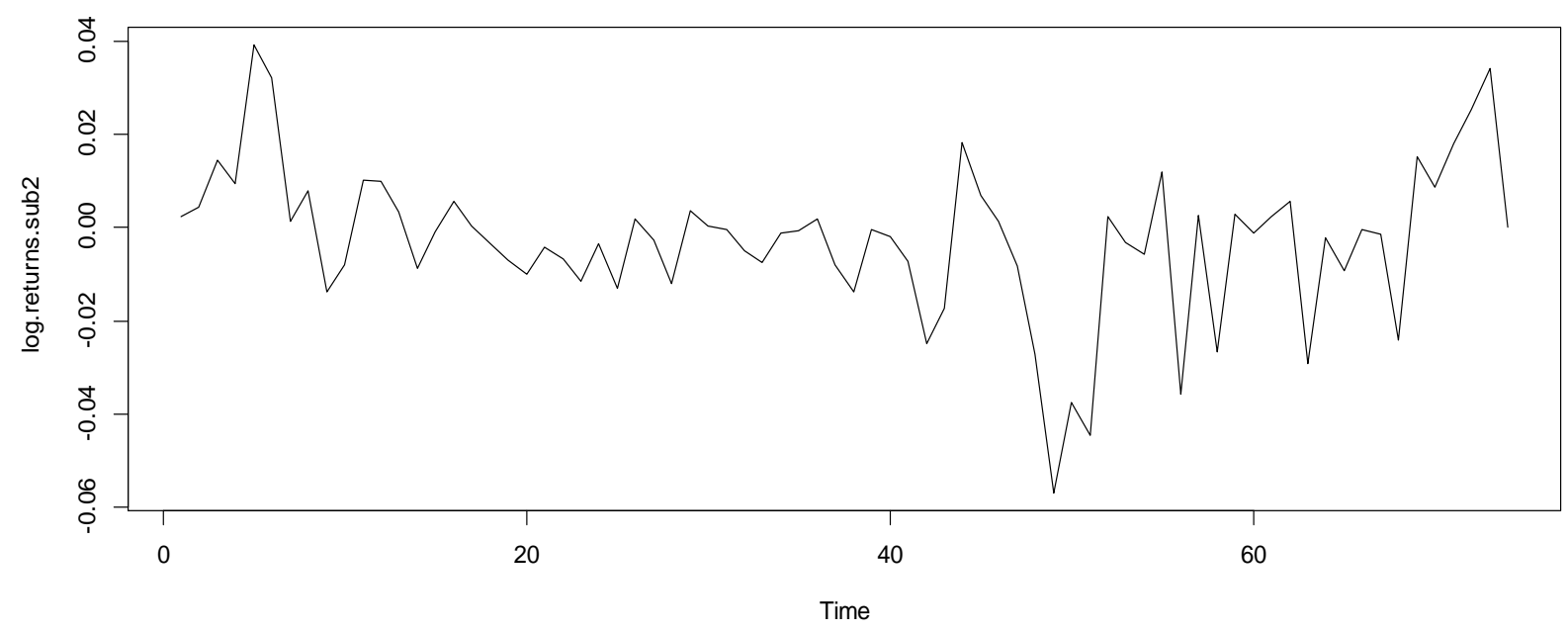

Fig 5: Time Plot for NSE log Returns for Covid 19 period 
Table 1: Data Summary

\begin{tabular}{|l|l|c|c|l|c|l|l|}
\hline Variables & Mean & Max. & Min. & SD & Skewness & Kurtosis & JB \\
\hline \multicolumn{7}{|c|}{ Daily Stock Price (Full Sample)(02/03/2015-16/04/2020) } \\
\hline Price & 1374.744 & 2062.610 & 871.2600 & 251.4658 & 0.639316 & 2.606262 & $\mathbf{9 4 . 7 1 7 1 9}$ \\
\hline \multicolumn{7}{|c|}{ Changes in Prices (Log-Returns) (03/03/2015-16/04/2020) } \\
\hline Returns & -0.000283 & 0.084240 & -0.056980 & 0.010800 & 0.459354 & 8.656373 & 1736.340 \\
\hline
\end{tabular}

In bold significant Jarque-Bera (JB) test at $5 \%$ level of significance.

Table 2: Data Summary for Non-COVID 19 and COVID-19 periods

\begin{tabular}{|l|l|c|c|c|c|c|c|}
\hline Variables & Mean & Max. & Min. & SD & Skewness & Kurtosis & JB \\
\hline \multicolumn{7}{|c|}{ Changes in Prices (Sub Sample)(Non Covid 19 period)(03/03/2015-31/12/2019) } \\
\hline Returns & -0.000133 & 0.084240 & -0.046310 & 0.010370 & 0.728786 & 8.878462 & $\mathbf{1 8 2 6 . 4 0 0}$ \\
\hline \multicolumn{7}{|c|}{ ARCH LM-test: Chi-squared = 148.46, df = 12, p-value < 2.2e-16 } \\
\hline Changes in Prices (Sub Sample)(Covid 19 period)(02/01/2020-16/04/2020) \\
\hline Returns & -0.002701 & 0.039280 & -0.056980 & 0.016152 & -0.507240 & 4.889446 & $\mathbf{1 4 . 1 8 0 7 9}$ \\
\hline \multicolumn{7}{|c|}{ ARCH LM-test: Chi-squared = 28.377, df = 12, p-value = 0.00487} \\
\hline
\end{tabular}

In bold significant Jarque-Bera (JB) test at $5 \%$ level of significance. 
Table 3: Results of classical Unit root tests for the full sample

\begin{tabular}{|lr|r|r|}
\hline Variables & ADF & DF-GLS & PP \\
\hline & \multicolumn{1}{|c|}{ Daily Stock Price (Full Sample)(02/03/2015-16/04/2020) } \\
\hline Price & -1.263209 & -1.377705 & -1.048394 \\
\hline \multicolumn{4}{|c|}{ Changes in Prices (Log-Returns) (02/03/2015-16/04/2020) } \\
\hline Returns & $-\mathbf{- 1 2 . 8 7 2 3 8}$ & -3.236530 & -25.29883 \\
\hline
\end{tabular}

The bold denoted evidence of no unit root in the series.

Table 4: Results of classical Unit root tests for non Covid 19 and Covid 19 periods

\begin{tabular}{|c|c|c|c|}
\hline Variables & ADF & DF-GLS & PP \\
\hline \multicolumn{4}{|c|}{$\begin{array}{r}\text { Changes in Prices (Sub Sample)(Non Covid } 19 \text { period)(03/03/2015- } \\
31 / 12 / 2019)\end{array}$} \\
\hline Returns & -12.89569 & -2.585696 & -24.70057 \\
\hline \multicolumn{4}{|c|}{ Changes in Prices (Sub Sample)(Covid 19 period)(02/01/2020- } \\
\hline Returns & -3.821792 & -3.906051 & -5.414277 \\
\hline
\end{tabular}

The bold denoted evidence of no unit root in the series. 
Table 5: Results of GARCH Models for Full Sample

\begin{tabular}{|l|c|c|c|c|c|}
\hline Models & Distributions & AIC & BIC & SBIC & HQIC \\
\hline \multicolumn{7}{|c|}{ Log returns Full Sample } \\
\hline eGARCH(1,1) & GED & -6.5519 & -6.5316 & -6.5519 & -6.5443 \\
eGARCH(1,2) & GED & -6.5503 & -6.5259 & -6.5503 & -6.5411 \\
eGARCH(2,1) & GED & -6.5487 & -6.5203 & -6.5487 & -6.5380 \\
eGARCH(2,2) & GED & -6.5485 & -6.5160 & -6.5485 & -6.5363 \\
eGARCH(1,1) & STD & -6.5537 & -6.5335 & -6.5538 & -6.5461 \\
eGARCH(1,2) & STD & -6.5520 & -6.5276 & -6.5520 & -6.5428 \\
eGARCH(2,1) & STD & -6.5504 & -6.5220 & -6.5504 & -6.5397 \\
eGARCH(2,2) & STD & -6.5496 & -6.5172 & -6.5497 & -6.5375 \\
eGARCH(1,1) & SSTD & -6.5554 & -6.5311 & -6.5555 & -6.5463 \\
eGARCH(1,2) & SSTD & -6.5537 & -6.5253 & -6.5537 & -6.5430 \\
eGARCH(2,1) & SSTD & -6.5521 & -6.5197 & -6.5522 & -6.5400 \\
eGARCH(2,2) & SSTD & -6.5517 & -6.5152 & -6.5518 & -6.5380 \\
QGARCH(1,1) & GED & -6.5526 & & -6.5323 & -6.5450 \\
QGARCH(1,2) & GED & -6.5517 & & -6.5273 & -6.5426 \\
QGARCH(2,1) & GED & -6.5520 & & -6.5276 & -6.5428 \\
QGARCH(2,2, & GED & -6.5506 & & -6.5222 & -6.5399 \\
QGARCH(1,1) & STD & -6.5552 & & -6.5349 & -6.5476 \\
QGARCH(1,2) & STD & -6.5541 & & -6.5298 & -6.5450 \\
QGARCH(2,1) & STD & -6.5542 & & -6.5299 & -6.5451 \\
QGARCH(2,2, & STD & -6.5527 & & -6.5243 & -6.5420 \\
\hline
\end{tabular}

Table 6: eGARCH(1,1) with Dummy Variable

\begin{tabular}{|l|l|r|r|r|r|r|r|}
\hline Model & $\omega$ & \multicolumn{1}{|c|}{$\alpha_{1}$} & \multicolumn{1}{|c|}{$\beta_{1}$} & \multicolumn{1}{l|}{$\gamma_{1}$} & Covid 19 & \multicolumn{1}{l|}{ Skew } & \multicolumn{1}{l|}{ Shape } \\
\hline \multicolumn{7}{|c|}{ Optimal Parameters } \\
\hline eGARCH(1,1) & -0.95100 & -0.20743 & 0.90029 & 0.59624 & -5.57650 & 1.00000 & 3.99777 \\
& $(0.000593)$ & $(0.000130)$ & $(0.000706)$ & $(0.000332)$ & $(0.002064)$ & $(0.000895)$ & $(0.004000)$ \\
\hline \multicolumn{7}{|c|}{ Persistence= 0.9002867; Half-life= 6.598761 } \\
\hline
\end{tabular}

